\title{
Reproductive parameters in a Banija Spotted pig breed population during breed revitalization
}

\author{
Sven Menčik ${ }^{1}$, Vedran Klišanić², Marija Špehar² ${ }^{2}$ Željko Mahnet ${ }^{2}$, \\ Dubravko Škorput ${ }^{3}$, Zoran Luković’ ${ }^{3}$, Danijel Karolyi ${ }^{4}$, \\ Anamaria Ekert Kabalin ${ }^{1}$, and Krešimir Salajpal ${ }^{4 *}$ \\ ${ }^{I}$ Department of Animal Breeding and Livestock Production, Faculty of Veterinary Medicine, University of \\ Zagreb, Zagreb, Croatia \\ ${ }^{2}$ Croatian Agricultural Agency, Zagreb, Croatia \\ ${ }^{3}$ Department of Animal Science and Technology, Faculty of Agriculture, University of Zagreb, Zagreb, Croatia \\ ${ }^{4}$ Department of Animal Science, Faculty of Agriculture, University of Zagreb, Zagreb, Croatia
}

\begin{abstract}
MENČIK, S., V. KLIŠANIĆ, M. ŠPEHAR, Ž. MAHNET, D. ŠKORPUT, Z. LUKOVIĆ, D. KAROLYI, A. EKERT KABALIN, K. SALAJPAL: Reproductive parameters in a Banija Spotted pig breed population during breed revitalization. Vet. arhiv 89, 183-199, 2019.
\end{abstract}

\section{ABSTRACT}

The aim of the study was to evaluate reproductive parameters in a population of the Banija Spotted (BS) pig breed. A total of 69 breeding sows registered in the herdbook were analysed according to the Order of Parity $(\mathrm{OP})\left(1^{\text {st }}, 2^{\text {nd }}, 3^{\text {rd }}\right.$, joint $4^{\text {th }}$ and $5^{\text {th }}$ parity, and all parities $)$. Basic descriptive statistical analyses were used to calculate reproductive parameters such as age at mating and farrowing, Age of the Boar (AB) at mating, gestation length and farrowing interval; the following parameters were analysed for Litter Size (LS): Total Number of Born (TNB), Number of Born Alive (NBA), Number of Still Born (NSB) and Number of Weaned (NW) piglets. Analyses were carried out using the GLM procedure in SAS, whereas the Pairwise Pearson PROC CORR procedure was used to calculate correlation coefficients (r) between LS traits. On average 8.26 TNB, $7.57 \mathrm{NBA}, 0.67 \mathrm{NSB}$ and $6.95 \mathrm{NW}$ piglets were determined. Significant differences $(\mathrm{P}<0.05)$ were observed between $1^{\text {st }}$ and $2^{\text {nd, }}$ and $1^{\text {st }}$ and $3^{\text {rd }} \mathrm{OP}$ for TNB and NBA. NW was significantly different $(\mathrm{P}<0.05)$ between $1^{\text {st }}$ and $2^{\text {nd }} \mathrm{OP}$, and between $3^{\text {rd }}$ and joint $4^{\text {th }}$ and $5^{\text {th }}$ parities, with a significant $(\mathrm{P}<0.05)$ effect of Gestation Length (GL) and Farrowing Season (FS) on NBA in $2^{\text {nd }}$ parity. A significant effect of Herd Group (HG) and AB on NBA was recorded in $3^{\text {rd }} \mathrm{OP}$. Joint $4^{\text {th }}$ and $5^{\text {th }}$ parities with the lowest number of litters analysed showed a significant effect $(\mathrm{P}<0.05)$ of $\mathrm{AB}$ on TNB, NBA and NW, as well as of GL on NSB. High correlation coefficients $(\mathrm{r}=$ $0.7-0.9 ; \mathrm{P}<0.05$, per parity analysed) were found between TNB-NBA, TNB-NW and NBA-NW in all parities

\footnotetext{
*Corresponding author:

Prof. Krešimir Salajpal, DVM, PhD, Department of Animal Science, Faculty of Agriculture, University of Zagreb, Svetošimunska 25, HR-10000 Zagreb, Croatia, Phone: +385 12394 038; E-mail: ksalajpal@agr.hr
} 
and single parity analysed, with the highest value recorded between NBA-NW in the joint $4^{\text {th }}$ and $5^{\text {th }}$ parities $(\mathrm{r}=0.94)$. According to the analysed LS traits, Banija Spotted pig breed is characterised by moderate fertility.

Key words: Banija Spotted pig; sows; litter size; revitalization

\section{Introduction}

The loss of biodiversity in pig breeding has unfavourable impact on animal production sustainability in marginal areas, agricultural policies and demographic trends of rural regions (FAO, 2007). The ancient pig breeds of each country are an integral part of the genetic diversity, demographic and cultural heritage of the region. Historically, local breeds of pigs had a considerable share in the local population's diet as a valuable source of meat and fat (MICHAILIDOU et al., 2014). Revitalisation and preservation of indigenous breeds of domestic animals is a complex procedure with the aim of recovering, raising and preserving the breed, according to traditional practices specific for the species and breed (DOMÍNGUEZ et al., 2015).

History and presence of the breed. According to ŠRAM (1950), a significant effect of the Berkshire breed boar on improving the domestic White lop-eared pig (presumably of Landrace breed type) was recorded in the first half of the $20^{\text {th }}$ century. Sow improvement with Berkshire breed boars was aimed at promoting the reproductive and production features of domestic White pigs. In addition, ILANČIĆ (1958) describes the significant impact of Berkshire breed boars on the population of the Turopolje pig breed with the aim of breed improvement. Due to continuous crossbreeding over generations, crossbreds with local pigs were phenotypically significantly different from their original. They were characterized by greater black hair areas, as one of the dominant features of the Berkshire breed. In the mid- $20^{\text {th }}$ century, these pigs were named the Banija Spotted pig breed. Similar descriptions of phenotypic features and characteristic spot distribution have been reported by VUKINA (1961) and GUGIĆ and POSAVI (2000).

The introduction of modern genotypes in the middle of the second half of the $20^{\text {th }}$ century, almost led to the extinction but also the erosion of many local pig breeds (ALFONSO et al., 2005). This was confirmed by VENTANAS et al. (2007) reporting that $80 \%$ of Iberian sows were used for crossing with Durocs to improve the production profitability of the native pig breeds. GROENEVELD et al. (2010) also reported a considerable decline in the number of native pig breeds as a consequence of the ever increasing consumer pressure and the role of animal fat in human nutrition.

Over recent decades, pigs of the Banija Spotted breed type were considered to have become extinct in the middle of the $20^{\text {th }}$ century as a local genotype of pig with the main population remaining in the Banija region. Continuous monitoring of the population of Banija Spotted type pigs in the last ten years has recorded a small number of pigs corresponding to the type and marked as a Banija Spotted pig breed population according 
to their phenotypic characteristics (as a remainder of a cross population of 'Banija Spotted' pig breed type). Extensive or semi-extensive conditions over decades were one of the major factors that led to the presence of a small number of pigs within family breeding farms by a small group of breeders raising Banija Spotted pigs at the beginning of the millennium, currently pigs of combined production features (meat and fat type), primarily intended for the production of traditional cured meat products and high-quality fat.

When the herdbook was established by the Croatian Agricultural Agency for the National Pedigree Register, 14 animals were defined as founders (BIERMANN et al., 2014), including 9 sows and 5 boars (ANONYM., 2016).

At the end of 2017, the number of Banija Spotted pig breed population in the National Pedigree Register had risen to 69 breeding females and 19 males for reproduction in 14 herds, with targeted mating to minimize the rate of inbreeding in the population of Banija Spotted pig. During the revitalization program, natural mating was present in the population, moreover, with at least one boar present in the herd.

Reproductive traits of the Banija Spotted pig breed. Based on their phenotypic traits in comparison to Turopolje and Black Slavonian pig breeds, sows of the Banija Spotted pig breed have predominantly inherited a large body frame, and higher fertility (ANONYM., 2016). According to historical records (ŠRAM, 1950), sow fertility versus other native breeds is high, with 8 to 14 piglets per litter and 6 to 7 well developed pairs of teats (Fig. 1). Gilts are capable of mating at the age of 10 months, and young boars at the age of one year. Adult breeding sows weigh 150-200 or even more kilograms. High rusticity and a high level of adaptability to the local natural environment, in particular in a pasture raising system, have enabled the proper establishment of all productivity characteristics over generations, with a primary emphasis on high fertility.

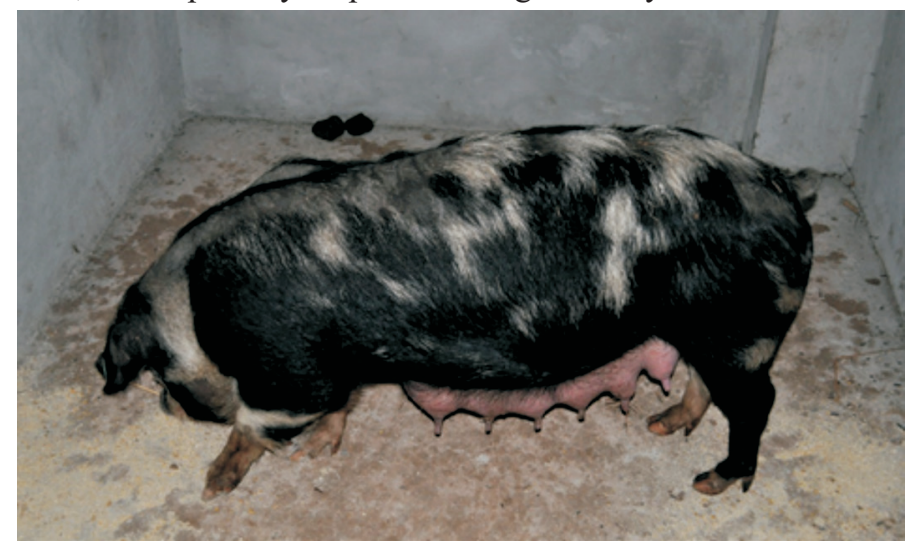

Fig. 1. Sows of Banija Spotted pig breed, Trgovi (Dvor), 2017 (Photo: Menčik and Salajpal, 2017) 
Considering that the Banija Spotted pig population has been raised in small herds, the genetic contribution of the founder population to the current population of breeding pigs is of relevance (FERNANDES et al., 2010) in selecting males and females within the active population for the next generations from the area of origin (SABBIONI et al., 2011). Therefore, a sustainable breeding strategy in the present population is key for minimized inbreeding, as well as to preserve genetic variation within the Banija Spotted pig breed population (BIERMANN et al., 2014). According to KÖCK et al. (2009), it is well known that lower genetic variability and higher occurrence of inbreeding have an unfavourable impact on fertilization capacity, mortality and embryo viability in pigs.

There are no records in scientific articles about the reproductive parameters of the Banija spotted pig breed, so the aims of this study were to: analyse reproduction characteristics in subsequent parities of sows, estimate fixed and random factors within the studied characteristics, and to find out if there is any relationship between litter size and subsequent parities in this breed of pig.

\section{Materials and methods}

The study was performed on 69 Banija Spotted pig breed sows registered in the National Pedigree Register, from March 2014 to February 2018. Data were collected on the reproductive performance of the Banija Spotted pig breed population including date of sow birth, service and farrowing according to OP, and data on boar age with litter size data per sow. Basic statistical parameters, i.e. Mean \pm Standard Deviation (Mean $\pm \mathrm{SD}$ ) and Coefficient of Variation $(\mathrm{CV} \%)$ for reproductive parameters from the $1^{\text {st }}$ to $5^{\text {th }}$ parity were calculated from data in the herdbook. The indicators of litter size were analysed individually for the first three farrowings, then for the $4^{\text {th }}$ and $5^{\text {th }}$ farrowings, and for the $1^{\text {st }}$ to $5^{\text {th }}$ parities pooled together.

Statistical analysis was carried out with the Least Square Method by the General Linear Model (GLM) procedure using SAS software v. 9.4 (SAS, 2010). Linear equation of the model:

$\mathrm{Y}_{\mathrm{ijklmnop}}=\mu+\mathrm{AGE}^{\mathrm{st}} \mathrm{F}_{\mathrm{i}}+\mathrm{OP}_{\mathrm{j}}+\mathrm{GL}_{\mathrm{k}}+\mathrm{HG}_{1}+\mathrm{FS}_{\mathrm{m}}+\mathrm{LLG}_{\mathrm{n}}+\mathrm{AB}_{\mathrm{o}}+\mathrm{e}_{\mathrm{ijklmnop}}$

where

$\mathrm{Y}_{\mathrm{ijklmnop}}$ is the value of litter size traits (TNB, NBA, NSB and NW);

$\mu$ is the overall mean;

AGE ${ }^{1 s t} F i$ - AGE at first $\left(1^{\text {st }}\right)$ Farrowing $(i=1,2)$ was included as a fixed effect in the model with two levels, with sows farrowing under one year of age as the first level and sows farrowing at $>366$ days of age as the second level;

$\mathrm{OP}_{\mathrm{j}}$ - Order of Parity was included in the analyses of all parities, from $1^{\text {st }}$ to $5^{\text {th }}$ parities;

$\mathrm{GL}_{\mathrm{k}}$ - Gestation Length defined in two groups $(\mathrm{k}=1,2)$, i.e. sows farrowing in the interval between day 113 and day 115, with the second group beyond this interval. During the study period, Herd Group was defined for each breeder according to the number of active sows, as follows: 


\section{S. Menčik et al.: Reproductive parameters in Banija Spotted pig breed}

$\left(\mathrm{HG}_{1}\right)$ level $(1=1,2)$ Herd Group: 1 to 4 reproductive sows per herd as the first group and 5 to 10 reproductive sows per herd as the second group. For each year of calculation,

$\mathrm{FS}_{\mathrm{m}}$ - Farrowing Season was formed as the interaction between the year and month of farrowing in the investigated period $(\mathrm{m}=1,2,3, \ldots 12)$;

$L_{L G}$ - Lactation Length Group was defined according to management routines in the herd with piglets, i.e. piglets that were weaned by the $6^{\text {th }}$ week of age as the first group and piglets weaned from the $7^{\text {th }}$ to $8^{\text {th }}$ weeks of age as the second group;

$\mathrm{AB}_{\mathrm{o}}$ - effect of the Age of the Boar $(\mathrm{o}=1,2)$ as a fixed effect according to service age, young boars aged $<2$ and $>2$ years;

$\mathrm{e}_{\mathrm{ijklmnop}}$ - residual random effect error.

When testing all the effects in the linear equation model, LLG was excluded from the statistical model of calculation because there was no statistical significance $(\mathrm{P}>0.05)$ or tendency $(\mathrm{P}<0.1)$ of influence on litter size traits. According the backward step down selection model of calculation, in first parity sows, $A G E^{1 s t} F, H G, F S$ and $A B$ were included in the model of calculation. For $2^{\text {nd }}, 3^{\text {rd }}$ and joint $4^{\text {th }}$ with $5^{\text {th }} \mathrm{OP}$, effects of GL, HG, FS and $\mathrm{AB}$ were defined, as well as of $\mathrm{OP}$, which was included in the pooled farrowing analysis.

For each parity, the analysis of variance of the effects included in the model of calculation was presented in the population of Banija Spotted pig breed. The PROC CORR Pairwise Pearson Correlation Coefficients were used to calculate litter size traits. Values lower than $0.05(\mathrm{P}<0.05)$ were considered as significantly different, while the probability ranging from 0.051 to 0.10 tended to be significantly different.

\section{Results}

The results obtained by descriptive statistical analyses of reproductive parameters according to data collected from the herdbook are shown in Table 1.

Table 1. Reproductive traits relating to subsequent parities of Banija spotted pigs

\begin{tabular}{|l|c|c|c|c|c|}
\hline \multirow{2}{*}{} & \multicolumn{5}{|c|}{ Calculated reproductive value according to order of parity in days } \\
& \multicolumn{5}{|c|}{ (Mean \pm SD; Coefficient of Variation\%) } \\
\cline { 2 - 6 } Item & $\begin{array}{c}\text { First parity } \\
\mathrm{n}=69\end{array}$ & $\begin{array}{c}\text { Second parity } \\
\mathrm{n}=41\end{array}$ & $\begin{array}{c}\text { Third parity } \\
\mathrm{n}=24\end{array}$ & $\begin{array}{c}\text { Fourth parity } \\
\mathrm{n}=7\end{array}$ & $\begin{array}{c}\text { Fifth parity } \\
\mathrm{n}=4\end{array}$ \\
\hline Age at mating & $346 \pm 102$ & $550 \pm 136$ & $746 \pm 111$ & $943 \pm 79$ & $1190 \pm 189$ \\
(days) & $29.51 \%$ & $24.76 \%$ & $14.90 \%$ & $8.31 \%$ & $15.90 \%$ \\
\hline Age at farrowing & $460 \pm 102$ & $664 \pm 136$ & $860 \pm 112$ & $1145 \pm 219$ & $1305 \pm 187$ \\
(days) & $22.27 \%$ & $20.53 \%$ & $13.02 \%$ & $19.18 \%$ & $14.96 \%$ \\
\hline Gestation length & $113 \pm 1.63$ & $114 \pm 1.53$ & $114 \pm 1.82$ & $116 \pm 2.48$ & $115 \pm 2.44$ \\
(days) & $1.43 \%$ & $1.39 \%$ & $1.59 \%$ & $2.13 \%$ & $2.12 \%$ \\
\hline Age of the boar & $507 \pm 237$ & $584 \pm 272$ & $580 \pm 117$ & $690 \pm 161$ & $608 \pm 210$ \\
(days) & $46.77 \%$ & $46.72 \%$ & $30.66 \%$ & $35.26 \%$ & $34.56 \%$ \\
\hline Farrowing interval & & $195 \pm 36^{\mathrm{A}} \%$ & $213 \pm 44^{\mathrm{A}}$ & $198 \pm 32^{\mathrm{A}}$ & $239 \pm 47^{\mathrm{A}}$ \\
(days) & & $18.66 \%$ & $21.07 \%$ & $16.32 \%$ & $19.67 \%$ \\
\hline
\end{tabular}

${ }_{\mathrm{A}}$ - the values in the same row refer to the difference between the current and the previous farrowing; SD standard deviation 
High variability was found for the parameters of age at mating and age at $1^{\text {st }}$ and $2^{\text {nd }}$ farrowing. The age of the boar at service showed the highest variability in $1^{\text {st }}$ and $2^{\text {nd }}$ parity sows and the lowest variability in $3^{\text {rd }}$ parity sows. The length of gestation was comparable during the first three farrowings, with slightly higher values in the $4^{\text {th }}$ and $5^{\text {th }}$ parities. The lowest calculated farrowing interval values were recorded between the $1^{\text {st }}$ and $2^{\text {nd }}$ parities with $195 \pm 36$ days and $18.66 \% \mathrm{CV}$, with slightly higher values between the $3^{\text {rd }}$ and $4^{\text {th }}$ parities with $198 \pm 32$ days and $16.32 \% \mathrm{CV}$. Higher values were found between the $2^{\text {nd }}$ and $3^{\text {rd }}$ parities ( $213 \pm 44$ days; $21.07 \% \mathrm{CV}$ ), whereas the longest period was recorded between the $4^{\text {th }}$ and $5^{\text {th }}$ parities ( $239 \pm 47$ days; $19.67 \% \mathrm{CV}$ ).

The estimated values of litter size traits according to order of parity are presented in Table 2. A significant difference $(\mathrm{P}<0.05)$ was found between $1^{\text {st }}$ and $2^{\text {nd }}$ parity and $1^{\text {st }}$ and $3^{\text {rd }}$ parity sows for TNB and NBA, with a tendency for NBA $(\mathrm{P}<0.1)$ between $1^{\text {st }}$ and joint $4^{\text {th }}$ with $5^{\text {th }}$ parities. The NW trait in $1^{\text {st }}$ parity sows was significantly different $(\mathrm{P}<0.05)$ from NW in $2^{\text {nd }}, 3^{\text {rd }}$ and joint $4^{\text {th }}$ with $5^{\text {th }}$ parity sows. Evaluation of NSB yielded no significant difference between parities, with the lowest and highest values recorded in $2^{\text {nd }}$ and $3^{\text {rd }}$ parity sows, respectively.

Table 2. Litter size traits according to order of parity in a Banija Spotted pig breed population

\begin{tabular}{|l|c|c|c|c|c|}
\hline \multirow{2}{*}{} & \multicolumn{5}{|c|}{ LSM \pm SE for litter size traits according to order of parity } \\
\cline { 2 - 6 } & $\begin{array}{c}\text { All } \\
\text { parities } \\
\mathrm{n}=145\end{array}$ & $\begin{array}{c}\text { First } \\
\text { parity } \\
\mathrm{n}=69\end{array}$ & $\begin{array}{c}\text { Second } \\
\text { parity } \\
\mathrm{n}=41\end{array}$ & $\begin{array}{c}\text { Third } \\
\text { parity } \\
\mathrm{n}=24\end{array}$ & $\begin{array}{c}\text { Four and fifth } \\
\text { parities } \\
\mathrm{n}=11\end{array}$ \\
\hline TNB & $8.26 \pm 0.46$ & $7.35 \pm 0.30^{\mathrm{a}}$ & $8.35 \pm 0.36^{\mathrm{b}}$ & $8.79 \pm 0.49^{\mathrm{b}}$ & $8.56 \pm 0.72$ \\
\hline NBA & $7.57 \pm 0.43$ & $6.64 \pm 0.27^{\mathrm{a}, \mathrm{c}}$ & $7.74 \pm 0.34^{\mathrm{b}}$ & $8.04 \pm 0.45^{\mathrm{b}}$ & $7.89 \pm 0.67^{\mathrm{d}}$ \\
\hline NSB & $0.67 \pm 0.23$ & $0.68 \pm 0.15$ & $0.60 \pm 0.18$ & $0.75 \pm 0.25$ & $0.64 \pm 0.37$ \\
\hline NW & $6.95 \pm 0.42$ & $5.83 \pm 0.26^{\mathrm{a}}$ & $7.20 \pm 0.33^{\mathrm{b}}$ & $7.36 \pm 0.44^{\mathrm{b}}$ & $7.47 \pm 0.65^{\mathrm{b}}$ \\
\hline
\end{tabular}

LSM - Least Square Mean; SE - Standard Error; TNB - Total Number of Born piglets; NBA - Number of piglets Born Alive; NSB - Number of Still Born piglets; NW - Number of Weaned piglets; $\mathrm{n}$ - number of analysed litter; a,b - values in the same rows with different letters differ significantly $(\mathrm{P}<0.05)$; ${ }^{\mathrm{c}, \mathrm{d}}$ - values in the same rows with different letters differ with tendency $(\mathrm{P}<0.1)$

The coefficient of determination $\left(\mathrm{R}^{2}\right)$ of the models and significance (P-value) of the effects fitted for traits analysed in the Banija Spotted pig breed population are shown in Table 3. Pooled parity analysis revealed a significant effect of order of parity $(\mathrm{P}<0.05)$ on TNB, NBA and NW. The age of the boar in all parities analysed showed a tendency $(\mathrm{P}<0.1)$ for NSB. In $2^{\text {nd }}$ parities, there was a significant effect of gestation length and farrowing season $(\mathrm{P}<0.05)$ on NBA.

The herd group and age of the boar traits had a significant effect $(\mathrm{P}<0.05)$ on NW in $3^{\text {rd }}$ parity sows, whereas the farrowing season showed a tendency $(\mathrm{P}<0.1)$ for the effects 


\section{S. Menčik et al.: Reproductive parameters in Banija Spotted pig breed}

included in the model of calculation for NW and NSB, as well as the effect of the age of the boar on NBA. Joint $4^{\text {th }}$ and $5^{\text {th }}$ parities, with the lowest number of litters analysed, showed a significant effect $(\mathrm{P}<0.05)$ of the age of the boar on TNB, NBA and NW piglets, as well as of gestation length on NSB. In the same parities, the farrowing season showed a tendency $(\mathrm{P}<0.1)$ on TNB and NSB, and gestation length on TNB.

Table 3. Coefficient of determination $\left(\mathrm{R}^{2}\right)$ of the models and significance (P-value) of the effects fitted for trait analysed in a Banija Spotted pig breed population

\begin{tabular}{|c|c|c|c|c|c|c|c|c|}
\hline \multirow{2}{*}{$\begin{array}{c}\text { Order of } \\
\text { Parity }\end{array}$} & \multirow{2}{*}{$\begin{array}{c}\text { Litter } \\
\text { size trait }\end{array}$} & \multicolumn{7}{|c|}{ Variance of the effects included in the model of calculation } \\
\hline & & $\mathrm{R}^{2}(\%)$ & AGE1stF & OP & GL & $\mathrm{HG}$ & FS & $\mathrm{AB}$ \\
\hline \multirow{4}{*}{$\begin{array}{l}\text { All parities } \\
(\mathrm{n}=145)\end{array}$} & TNB & 12.60 & n. i. & $*$ & 0.85 & 0.17 & 0.34 & 0.37 \\
\hline & NBA & 12.77 & n. i. & $*$ & 0.53 & 0.13 & 0.47 & 0.98 \\
\hline & NSB & 13.71 & n. i. & 0.97 & 0.41 & 0.86 & 0.23 & $<0.1$ \\
\hline & NW & 6.94 & n. i. & $*$ & 0.86 & 0.36 & 0.77 & 0.66 \\
\hline \multirow{4}{*}{$\begin{array}{c}\text { First } \\
\text { parity } \\
(\mathrm{n}=69)\end{array}$} & TNB & 9.80 & 0.30 & n.i. & n.i & 0.27 & 0.52 & 0.51 \\
\hline & NBA & 6.10 & 0.73 & n.i. & n.i & 0.31 & 0.68 & 0.90 \\
\hline & NSB & 13.20 & 0.14 & n.i. & n.i & 0.98 & 0.25 & 0.16 \\
\hline & NW & 5.93 & 0.51 & n.i. & n.i & 0.54 & 0.29 & 0.79 \\
\hline \multirow{4}{*}{$\begin{array}{l}\text { Second } \\
\text { parity } \\
(\mathrm{n}=41)\end{array}$} & TNB & 16.41 & n.i. & n.i. & 0.15 & 0.95 & 0.23 & 0.76 \\
\hline & NBA & 30.18 & n.i. & n.i. & $*$ & 0.79 & $*$ & 0.81 \\
\hline & NSB & 9.17 & n.i. & n.i. & 0.34 & 0.75 & 0.79 & 0.29 \\
\hline & NW & 20.57 & n.i. & n.i. & 0.13 & 0.94 & 0.11 & 0.62 \\
\hline \multirow{4}{*}{$\begin{array}{l}\text { Third } \\
\text { parity } \\
(n=24)\end{array}$} & TNB & 14.18 & n.i. & n.i. & 0.36 & 0.37 & 0.66 & 0.41 \\
\hline & NBA & 29.26 & n.i. & n.i. & 0.28 & 0.63 & 0.30 & $<0.1$ \\
\hline & NSB & 38.07 & n.i. & n.i. & 0.94 & 0.29 & $<0.1$ & 0.22 \\
\hline & NW & 47.52 & n.i. & n.i. & 0.32 & $*$ & $<0.1$ & $*$ \\
\hline \multirow{4}{*}{$\begin{array}{l}\text { Joint fourth } \\
\text { and fifth } \\
\text { parities } \\
(\mathrm{n}=11)\end{array}$} & TNB & 94.22 & n.i. & n.i. & $<0.1$ & 0.16 & $<0.1$ & $*$ \\
\hline & NBA & 94.13 & n.i. & n.i. & 0.31 & 0.51 & 0.38 & $*$ \\
\hline & NSB & 86.43 & n.i. & n.i. & $*$ & 0.14 & $<0.1$ & 0.49 \\
\hline & NW & 87.63 & n.i. & n.i. & 0.84 & 0.83 & 0.71 & $*$ \\
\hline
\end{tabular}

OP - Order of Parity; AGE1stF - AGE at first farrowing; GL - Gestation Length; HG - Herd Group; FS Farrowing Season; AB - Age of the Boar; TNB - Total Number of Born piglets; NBA - Number of piglets Born Alive; NSB - Number of Still Born piglets; NW - Number of Weaned piglets; $\mathrm{n}$ - number of analysed litter; *differ significantly at $\mathrm{P}<0.05$; differ with tendency $\mathrm{P}<0.1 ;$ n.i. - not included in the model of calculation

The linear correlation coefficients (r) of the phenotypic value for litter size traits according to order of parity are presented in Table 4. Positive correlation coefficients were found between particular traits within the parities analysed. A partially positive and significant correlation $(\mathrm{P}<0.05)$ was recorded between TNB-NBA $(\mathrm{r}=0.87)$, NBA-NW 
S. Menčik et al.: Reproductive parameters in Banija Spotted pig breed

$(r=0.80)$, TNB-NW $(r=0.72)$ and TNB-NSB $(r=0.42)$ in all parities analysed. Slightly lower but significant $(\mathrm{P}<0.05)$ correlations compared with the pooled analysis were found in the $1^{\text {st }}$ parity for TNB-NBA $(r=0.84)$, TNB-NSB $(r=0.43)$, TNB-NW $(r=0.58)$ and NBA-NW $(r=0.66)$. In the $2^{\text {nd }}$ parity, the same correlation coefficient as in all parities analysed was recorded for TNB-NBA and TNB-NSB. Within the same parity, high and significant values $(\mathrm{P}<0.05)$ were recorded for TNB-NW $(r=0.82)$ and NBA-NW $(r=$ 0.95).

Table 4. Linear coefficient of correlation for litter size traits according to order of parity using pairwise Pearson correlation coefficients

\begin{tabular}{|c|c|c|c|c|}
\hline \multirow[b]{2}{*}{ Order of Parity } & \multicolumn{4}{|c|}{ Litter size trait } \\
\hline & & NBA & NSB & NW \\
\hline \multirow{4}{*}{$\begin{array}{l}\text { All parities } \\
(\mathrm{n}=145)\end{array}$} & TNB & $0.87^{*}$ & $0.42 *$ & $0.72 *$ \\
\hline & NBA & 1 & -0.07 & $0.80^{*}$ \\
\hline & NSB & & 1 & -0.01 \\
\hline & NW & & & 1 \\
\hline \multirow{5}{*}{$\begin{array}{l}\text { First parity } \\
(\mathrm{n}=69)\end{array}$} & & NBA & NSB & NW \\
\hline & TNB & $0.84^{*}$ & $0.43 *$ & $0.58^{*}$ \\
\hline & NBA & 1 & -0.09 & $0.66^{*}$ \\
\hline & NSB & & 1 & -0.02 \\
\hline & NW & & & 1 \\
\hline \multirow{5}{*}{$\begin{array}{l}\text { Second parity } \\
(\mathrm{n}=41)\end{array}$} & & NBA & NSB & NW \\
\hline & TNB & $0.87^{*}$ & $0.42^{*}$ & $0.82^{*}$ \\
\hline & NBA & 1 & -0.07 & $0.95^{*}$ \\
\hline & NSB & & 1 & -0.08 \\
\hline & NW & & & 1 \\
\hline \multirow{5}{*}{$\begin{array}{l}\text { Third parity } \\
(\mathrm{n}=21)\end{array}$} & & NBA & NSB & NW \\
\hline & TNB & $0.82 *$ & $0.46^{*}$ & $0.68^{*}$ \\
\hline & NBA & 1 & -0.11 & $0.71^{*}$ \\
\hline & NSB & & 1 & 0.08 \\
\hline & NW & & & 1 \\
\hline \multirow{5}{*}{$\begin{array}{l}\text { Joint Fourth and } \\
\text { fifth parities } \\
(\mathrm{n}=11)\end{array}$} & & NBA & NSB & NW \\
\hline & TNB & $0.93^{*}$ & 0.42 & $0.84^{*}$ \\
\hline & NBA & 1 & 0.06 & $0.94 *$ \\
\hline & NSB & & 1 & -0.05 \\
\hline & NW & & & 1 \\
\hline
\end{tabular}

TNB - Total Number of Born piglets; NBA - number of piglets Born Alive; NSB - Number of Still Born piglets; NW - Number of Weaned piglets; $n$ - number of analysed litter; *differ significanly at $\mathrm{P}<0.05$ 


\section{S. Menčik et al.: Reproductive parameters in Banija Spotted pig breed}

The lowest correlation coefficient $(\mathrm{P}<0.05)$ between TNB-NBA $(\mathrm{r}=0.82)$ was recorded in the $3^{\text {rd }}$ parity, with $r=0.46$ for TNB-NSB. Similar and higher values within the same parity were found between TNB-NW $(r=0.68)$ and NBA-NW $(r=0.71)$. The lowest number of litters in joint $4^{\text {th }}$ and $5^{\text {th }}$ parity showed significant correlations $(\mathrm{P}<0.05)$ between NBA-NW $(r=0.94)$, TNB-NBA $(r=0.93)$ and TNB-NW $(r=0.84)$.

\section{Discussion}

Revitalization and preservation of local pig genetic types is influenced by numerous factors, among them environmental changes and individual response as the primary key to survival for the current population (FERNANDEZ et al., 2010). Considering the role of the biodiversity of particular species and breeds in the modern world of animals, the sustainability of raising local pig breeds represents a national value and is of tremendous economic importance (RATKY et al., 2013). According to PUGLIESE and SIRTORI (2012), phenotype standardisation from the founder generation within the current populations is a key to prevent the possible loss of the present genotypes and eventually their possible extinction. Our study results regarding the basic reproductive parameters according to order of parity can be compared with local pig populations of similar phenotypic traits. According to the reproductive parameters evaluated, age at farrowing in $1^{\text {st }}$ and $2^{\text {nd }}$ parities in Banija Spotted pig breed was similar to the Krškopolje pig breed, with similar values obtained in higher parities as well (URANKAR et al., 2013). Furthermore, the mean age of farrowing value recorded in the Zlotnicka-Spotted pig breed indicated that farrowing occurred one month earlier in $1^{\text {st }}$ parity sows (SZULC et al., 2011) as compared with the mean value obtained for the Banija Spotted pig breed. In comparison with the Banija Spotted pig breed population, higher variability $(24.3 \%)$ of the age at farrowing was recorded in $1^{\text {st }}$ parity sows in the Turopolje pig breed population (KAROLYI et al., 2018). The high variability of the age at farrowing may be consequential to inhomogeneous breeding and housing conditions, the small number of breeding sows per herd, and the unevan conditions of reproduction management within the herd. PETROVIĆ et al. (2013) report on a significant difference in age at mating and age at farrowing between two herds of Mangalitza pig breed sows. The length of gestation per parity was consistent with the reports by NEVRKLA et al. (2017) on Přeštice BlackPied breed sows and PETROVIĆ et al. (2013) on Mangalitza breed sows. Results on farrowing interval traits consistent with those recorded in our study, i.e. a farrowing interval of 202-207 days in Zlotnicka-Spotted and a farrowing interval of 190-198 days in a Zlotnicka White pig breed population, were reported by SZULC et al. (2011). HORÁK et al. (2005) found lower mean farrowing interval values, ranging from 165.58 to 172.27 days. Considering the long-term presence of Přeštice Black-Pied pigs in the national program of genetic resources, NEVRKLA et al. (2017) report on lower mean farrowing interval values, ranging from $158.13 \pm 15.70$ to $173.92 \pm 23.93$ days. 
Based on all the main reproductive parameters analysed, it is evident that the high level of variability in the traits evaluated enables improvement and identification of homogenized indicators using clearly defined breeding and mating designs within the reproductive Banija Spotted pig breed populations. In comparison with Turopolje and Black Slavonian pig breeds, the Banija Spotted pig breed sows showed somewhat higher values of litter size traits, but these were significantly lower when compared to modern genetic pig types. Sows of the Banija Spotted pig breed can be compared with so-called 'black' or 'spotted' genotype pigs. Results similar to our findings have been described in Nero di Parma $1^{\text {st }}$ parity sows, i.e. TNB $7.3 \pm 2.1$, NBA $6.9 \pm 2.3$ and NW $5.5 \pm 2.7$ (MENČIK et al. 2015) and in Casertana $1^{\text {st }}$ parity sows with $7.75 \pm 0.6$ born alive and 5.37 \pm 0.5 weaned piglets (PIETROLÀ et al., 2006). In comparison with our study results, the Casertana breed $2^{\text {nd }}$ parity sows had significantly more born alive piglets $(10.36 \pm 0.7)$, similar to crosses with Large White (10.38 \pm 0.8$)$. However, a higher rate of NW piglets was recorded in Casertana breed $2^{\text {nd }}$ parity sows, with $8.82 \pm 0.6$ vs. $8.62 \pm 0.6$ piglets born alive in crosses with Large White. High results of litter size traits, as compared with the Banija Spotted pig type were recorded in Přšštice Black-Pied pig breed $1^{\text {st }}$ parity sows, with TNB 11.84, NBA 10.88 and NW 9.44 (HORÁK et al., 2005). The significantly lower number of weaned piglets in comparison to TNB and NBA in young sows may be due to several factors, including inadequately developed maternal instinct (GÄDE et al., 2008). CALDERÓN DIAZ et al. (2017) report that lower values of reproductive traits may be caused by inappropriate management conditions, e.g. stress before and during farrowing, lower birth weight, inappropriate care of piglets at the time of weaning, sow milk yield, and housing hygiene. In addition, inbreeding within the small population certainly contributes greatly to the decline in genetic diversity and future expression of the genetic potential for reproductive traits in pigs (BIERMANN et al., 2014). As local pig breeds are suitable for extensive or semi-extensive farming systems, the high birth weight and robustness of weaned piglets will significantly contribute to the high production potential of animals and the final quality of their products (PUGLIESE and SIRTORI, 2012). In the Banija Spotted pig population, litter size traits in higher farrowings are higher compared with Turopolje (KAROLYI et al., 2018) and Black Slavonian (MENČIK et al., 2015) pig populations, and are comparable to the litter size parameters recorded in the Italian population of the Sarda pig breed, with $8.83 \pm 1.17$ piglets at birth and $6.00 \pm 2.83$ at weaning (MAIORANO, 2009). Results similar to those recorded in the present study have been reported by MENČIK et al. (2017) in Nero di Parma sows with TNB $8.31 \pm$ 0.13 and NBA $8.01 \pm 0.15$, but with a slightly lower number of weaned piglets $(6.47 \pm$ 0.15 ). Litter performance in a Zlotnicka-Spotted pig breed population yielded TNB 8.82 \pm 0.42 , which is similar to our results for TNB, with higher NW (7.33 \pm 0.52$)$ (SZULC et al., 2011) relative to all parities analysed in the Banija Spotted pig population. According to SZYNDLER-NĘDZA et al. (2010), the mean litter size parameters for reproductive 
traits at birth are slightly higher in Polish autochthonous pigs, with 9.76 piglets born alive in Zlotnicka White and 9.06 in Zlotnicka-Spotted pig breed. Furthermore, PETROVIĆ et al. (2013) report on the results obtained in a population of Mangalitza pig breed sows kept in extensive conditions, which had a mean of 4.87 NBA with $4.80 \mathrm{NW}$ piglets in comparison to sows kept in an open system in the forest.

Fertility has always been considerably lower in local pig genotypes as compared with so-called white coat colour breeds of pigs, especially in a small pig population. Historical records on the population of the Banija Spotted pig breed describe wide use of crossbreeding methods with genetic introgression of commercial pig breeds, such as Landrace or Berkshire boars, in the mid- $20^{\text {th }}$ century. The aim of these crosses was to upgrade and promote the reproductive and production characteristics of the population of native pig breeds (BONNEAU and LEBRET, 2010). The considerably lower number of weaned piglets, i.e. a high proportion of piglet deaths in young sows, may primarily be due to piglet crushing (more than $75 \%$ in pig raising systems), followed by injury, diarrhoea and infection (MIAO et al., 2004). According to WHITTEMORE (2006), litter size performances increased with farrowing order until the $3^{\text {rd }}$ and $4^{\text {th }}$ parity, which is consistent with the results of our study. Good management of reproduction in small pig populations is considered one of the crucial steps to maintain good performance in pig breeding.

The impact of the order of parity was significant $(\mathrm{P}<0.05)$ on TNB, NBA and NW in all litters analysed. Results reported by MENČIK et al. (2017) revealed that parity also had a significant effect $(\mathrm{P}<0.05)$ on NBA and NW in pooled $\left(1^{\text {st }}\right.$ to $\left.10^{\text {th }}\right)$ farrowings when comparing Black Slavonian and Nero di Parma pig breeds. The length of gestation had a significant role $(\mathrm{P}<0.05)$ on NBA in $2^{\text {nd }}$ parity, and on NSB in joint $4^{\text {th }}$ and $5^{\text {th }}$ parities. The same parameters showed a tendency of effect $(\mathrm{P}<0.1)$ in joint $4^{\text {th }}$ and $5^{\text {th }}$ parities. Considering the limited body of data available for analysis, and the significant fertility difference between the $1^{\text {st }}$ and higher farrowings, it may be postulated that the higher piglet number in higher farrowings directly influenced the length of gestation (SASAKI and KOKETSU, 2006). The mentioned effect on litter size traits may also be a direct consequence of piglet maturing during the last days of gestation, which may increase or decrease the chance for piglet survival during farrowing.

The values obtained indicating a significant effect of the herd group $(\mathrm{P}<0.05)$ on NW only in the $3^{\text {rd }}$ parity may suggest that a more individualized approach to sows, especially during the time of farrowing, may have a favourable impact on NW piglets. A tendency towards the effect of the herd group $(\mathrm{P}<0.1)$ on NBA and NSB in $1^{\text {st }}$ parity sows and of reproductive data variability on NBA was also observed in the Mangalitza pig breed population. NSB was not influenced by the herd effect in the Mangalitza study, except for a significant effect $(\mathrm{P}<0.05)$ of $\mathrm{NW}$ on variability (PETROVIĆ et al., 2013). 
In the present study, farrowing season and age of the boar were a significant component in the analysis of litter size trait results. The significant effect of the farrowing season $(\mathrm{P}<0.05)$ on NBA in the $2^{\text {nd }}$ parity, with a tendency $(\mathrm{P}<0.1)$ recorded for NSB and NW in the $3^{\text {rd }}$ parity, and for TNB and NSB in the joint $4^{\text {th }}$ and $5^{\text {th }}$ parities, could be explained as the effect of extensive or semi-extensive breeding, specific for the population of Banija Spotted pigs. The potential for piglet survival showed a high correlation with the piglet birth weight, as well as with the farrowing season, which had a significant impact on the survival potential during the period of suckling (EKERT KABALIN et al., 2017). This was confirmed by the results of our study, showing that the farrowing season had a tendency $(\mathrm{P}<0.1)$ to influence litter size traits in higher parities in the Banija Spotted pig breed population, especially in larger litters with a greater number of piglets, with a tendency $(\mathrm{P}<0.1)$ of effect NW piglets.

The significant effects $(\mathrm{P}<0.05)$ of the age of the boar on TNB, NBA and NW in joint $4^{\text {th }}$ and $5^{\text {th }}$ parities may have been consequential to the limited number of cases, as well as to the poor management conditions of boars in the herd and their possible low sperm quality and quantity. According to KÖCK et al. (2009), mating with close relative boars can lead to inbreeding depression of reproductive traits, which is an inevitable consequence in small, endangered populations of pigs. As recorded in all parities analysed, the tendency for the effect $(\mathrm{P}<0.1)$ of the age of the boar on NSB suggests that future management and pedigree information to control the rate of inbreeding within the population of Banija Spotted pig breed would contribute to a better understanding of the impact of its effects on litter size in general. We can speculate that a small population is inbreeded and this fact affects some reproductive traits. In small pig populations, piglet survival is the key feature of sustainability and revitalization of the species/breed. Therefore, in the case of lowheritable characteristics such as reproductive traits, proper analysis, with an appropriate and practical approach using statistical methods is a key factor in interpreting future progress in litter size trait (KNOL et al., 2002). However, we can also accept the opposite, that the lower litter size in indigenous breeds is normal and good, while the animals are well adapted to extensive and semi extensive production systems.

In some circumstances, within a small indigenous pig population, genetic variability may be significantly reduced, resulting in a higher level of inbreeding and the related risk of breeding depression and a possible subsequent decrease in the breed productivity (MAIORANO, 2009). LENSTRA et al. (2012) state that genetic diversity of livestock species, in particular within and between local pig breeds, will help preserve the highest variability within the breed, and reduce the level of inbreeding in order to consolidate the desirable animal genotype and so equalise their production and reproduction features. For this reason, GAMA et al. (2013) report that evaluation and comparison of the genetic diversity of local pig breeds is required to prevent and conserve the possible loss of the 


\section{S. Menčik et al.: Reproductive parameters in Banija Spotted pig breed}

reservoir of the available gene pool, in order to maintain genetic variability in the future pig population.

\section{Conclusion}

The Banija Spotted pig breed is characterised by moderate fertility, in particular in relation to other local pig breeds with similar traits. Future strategies will be focused on designing sustainable breeding programs to improve management and rearing systems in order to increase the number of valid breeding animals, which is essential to maintain genetic diversity in future breeding. Reductions in litter variability and a better understanding of the genetic potential and environmental factors that influence reproductive traits in the Banija Spotted pig breed, will improve the survival rate until weaning. The process of Banija Spotted pig breed revitalization is a priority that will significantly influence the future genetic diversity in pig breeds worldwide.

\section{Acknowledgements}

The authors thank the breeders from the Banija Spotted Pig Breeders Society for their valuable cooperation and the Department for Pig Development of the Croatian Agricultural Agency for providing data relevant for the study. The study was supported by the Ministry of Agriculture of the Republic of Croatia, Council for Research in Agriculture, project title: Revitalization of Banija Spotted Pig Breed, No. 2015-13/42.

\section{References}

ALFONSO, L., J. MOUROT, K. INSAUSTI, J. A. MENDIZABAL, A. ARANA (2005): Comparative description of growth, fat deposition, carcass and meat quality characteristics of Basque and Large White pigs. Anim. Res. 54, 33-42.

DOI: 10.1051/animres:2005001

ANONYMOUS (2016): Pig breeding: annual report for 2016 year. Croatian Agricultural Agency. Križevci, Croatia. pp. 43-46.

BIERMANN, A. D. M., E. C. G. PIMENTAL, M. TIETZE, T. PINENT, S. KÖNIG (2014): Implementation of genetic evaluation and mating designs for the endangered local pig breed 'Bunte Bentheimer'. J. Anim. Breed. Genet. 131, 36-45.

DOI: $10.1111 /$ jbg. 12041

BONNEAU, M., B. LEBRET (2010): Production systems and influence on eating quality of pork. Meat Sci. 84, 293-300.

DOI: 10.1016/j.meatsci.2009.03.013

CAlderón DiAZ, J. A., A. DiAnA, L. A. BOYle, F. C. LEONARD, M. McElroy, S. McGETTRICK, J. MORIARTY, E. G. MANZANILLA (2017): Delaying pigs from the normal production flow is associated with health problems and poorer performance. Porcine Health Manag. 3, 1-6.

DOI: 10.1186/s40813-071-0061-6 
S. Menčik et al.: Reproductive parameters in Banija Spotted pig breed

DOMÍNGUEZ, R., M. SIDONIA, M. GÓMEZ, J. CARBALLO, I. FRANCO (2015): Fatty acids, retinol and cholesterol composition in various fatty tissues of Celta pig breed: effect of the use of chestnuts in the finishing diet. J. Food Compos. Anal. 37, 104-111.

DOI: $10.1016 /$ j.jfca.2014.08.003

EKERT KABALIN, A., T. BALENOVIĆ, M. ŠPERANDA, S. MILINKOVIĆ-TUR, I. ŠTOKOVIĆ, S. MENČIK, M. MAURIĆ, Ž. PAVIČIĆ (2017): Serum biochemical parameters in suckling piglets with low and average birth mass. Vet. arhiv. 87, 171-184.

FAO (2007): The State of the World's Animal Genetic Resources for Food and Agriculture. FAO, Rome.

FERNANDES, S. D., S. MALOVRH, M. KOVAC, V. A. P. CADAVEZ (2010): Study of genetic diversity of Bisaro pigs breed by pedigree analysis. Universitatea de Ştiinţe Agricole şi Medicină Veterinară Iaşi. Lucrări Ştiinţifice - Seria Zootehnie. 53, 326-330.

GÄDE, S., J. BENNEWITZ, K. KIRCHNER, H. LOOFT, P. W. KNAP, G. THALLER, E. KALM (2008): Genetic parameters for maternal behaviour traits in sows. Livest. Sci. 114, 31-41.

DOI: $10.1016 /$ j.livsci.2007.04.006

GAMA, L. T., A. M. MARTÍNEZ, I. CAROLINO, V. LANDI, J. V. DELGADO, A. A. VICENTE, J. L. VEGA-PLA, O. CORTÉS, C. O. SOUSA, and BIOPIG Consortium (2013): Genetic structure, relationships and admixture with wild relatives in native pig breeds from Iberia and its islands. Genet. Sel. Evol. 45:18.

DOI: $10.1186 / 1297-9686-45-18$

GROENEVELD, L. G., J. A. LENSTRA, H. EDING, M. A. TORO, B. SCHERF, D. PILLING, R. NEGRINI, E. K. FINLAY, H. JIANLIN, E. GROENEVELD, S. WEIGEND and The GLOBALDIV Consortium (2010): Genetic diversity in farm animals - a review. Anim. Genet. 41, 6-31.

DOI: 10.1111/j.1365-2052.2010.02038.x

GUGIĆ, G., M. POSAVI (2000): Program for the development of livestock production- Model of pasture use in Nature Park Lonjsko Polje. In: Agroecological Study and Program Development of Agriculture in the Sisak - Moslavina Country Area. Public Institution: Nature Park - Lonjsko polje (in Croatian).

HORÁK, P., T. URBAN, J. DVOŘÁK (2005): The FUT1 and ESR genes - their variability and associations with reproduction in Přsštice Black-Pied sows. J. Anim. Breed. Genet. 122, 210213.

DOI: 10.1111/j.1439-0388.2005.00502.x

ILANČIČ, D. (1958): Pig breeding: In: Issue Livestock Breeding (Hrasnica, F., S. Pavlović, A. Rako, I. Šmaljcelj, Eds.) pp. 293-411 (in Croatian).

KAROLYI, D., Z. LUKOVIĆ, D. ŠKORPUT, Ž. MAHNET, V. KLIŠANIĆ, I. VNUČEC, K. SALAJPAL, A. BOŠNJAK (2018): Morphological and reproductive traits of Turopolje breeding sows: a preliminary evaluation. Arch. Zootec. Proceedings IX Simposio International sobre el Cerdo Mediterráneo. pp. 57-59. 
S. Menčik et al.: Reproductive parameters in Banija Spotted pig breed

DOI: 10.21071/az.v67iSupplement.3207

KÖCK, A., B. FÜRST-WALTL, R. BAUMUNG (2009): Effects of inbreeding and number of piglets born total, born alive and weaned in Australian Large White and Landrace pigs. Archiv Tierzucht. 52, 51-64.

DOI: $10.5194 / \mathrm{aab}-52-51-2009$

KNOL, E. F., J. I. LEENHOUWERS, T. VAN DER LENDE (2002): Genetic aspects of piglets survival. Livest. Sci. 78, 47-55.

DOI: 10.1016/S0301-6226(02)00184-7

LENSTRA, J. A., L. F. GROENEVELD, H. EDING, J. KANTANEN, J. L. WILLIAMS, P. TABERLET, E. L. NICOLAZZI, J. SOLKNER, H. SIMIANER, E. CIANI, J. F. GARCIA, M. W. BRUFORD, P. AJMONE-MARSAN, S. WEIGEND (2012): Molecular tools and analytical approaches for the characterization of farm animal genetic diversity. Anim. Genet. 43, 483502.

DOI: 10.1111/j.1365-2052.2011.02309.x.

MAIORANO, G. (2009): Swine production in Italy and research perspectives for the local breeds. Slovak J. Anim. Sci. 42, 159-166.

MENČIK, S., M. ŠPEHAR, A. EKERT KABALIN, Ž. MAHNET, V. BERETTI, P. SUPERCHI, A. SABBIONI (2015): Estimate of litter size traits in two local pig breed populations in the Mediterranean region. Book of Abstract - Italian Journal of Animal Science., ASPA $21^{\text {st }}$ Congress, $9^{\text {th }}$ to $12^{\text {th }}$ June 2015 , pp. 117-118.

MENČIK, S., M. ŠPEHAR, Ž. MAHNET, D. KNEŽEVIĆ, M. OSTOVIĆ, V. BERETTI, P. SUPERCHI, A. SABBIONI (2017): Litter size traits in Black Slavonian and Nero di Parma pig breeds: effects of farrowing management and sow number per herd. Book of Abstracts - Italian Journal of Animal Science, ASPA 22 $2^{\text {nd }}$ Congress, 13-16 June, Perugia, Italy, pp. 145-146.

MIAO, Z. H., P. C. GLATZ, Y. J. RU (2004): Review of production, husbandry and sustainability of free-range pig production systems. Asian-Aust. J. Anim. Sci. 17, 1615-1634.

DOI: 10.5713 /ajas.2004.1615

MiChailidou, S., A. KAlivaS, I. GANOPOUlOS, E. STEA, G. MICHAILIDIS, A. TSAFTARIS, A. ARGIRIOU (2014): A multi-farm assessment of Greek black pig genetic diversity using microsatellite molecular markers. Genet. Mol. Res. 13, 2752-2765.

DOI: $10.4238 / 2014$.April.14.4.

NEVRKLA, P., E. VÁCLAVKOVÁ, Z. HADAŠ, P. HORKȲ (2017): Evaluation of reproductive performance in sows of Přšstice Black-Pied pig - Czech genetic resource. Indian J. Anim. Res. 51, 219-222.

DOI: $10.18805 /$ ijar.11172

PETROVIĆ, M., R. SAVIĆ, N. PARUNOVIĆ, D. RADOJKOVIĆ, Č. RADOVIĆ (2013): Reproductive traits of pigs of Mangalitsa breed. $8^{\text {th }}$ International Symposium on the Mediterranean Pig. Slovenia, Ljubljana, October $10^{\text {th }}$ to $12^{\text {th }}$. Acta Agr. Slov. 4, 89-92.

Vet. arhiv 89 (2), 183-199, 2019 
S. Menčik et al.: Reproductive parameters in Banija Spotted pig breed

PIETROLÀ, E., F. PILlA, G. MAIORANO, D. MATASSINO (2006): Morphological traits, reproductive and productive performances of Casertana pigs reared outdoors. Ital. J. Anim. Sci. 2, 139-146.

DOI: $10.4081 /$ ijas.2006.139

PUGLIESE, C., F. SIRTORI (2012): Quality of meat and meat products produced from southern European pig breeds. Meat Sci. 90, 511-518.

DOI: 10.1016/j.meatsci.2011.09.019

RÁTKY, J., I. EGERSZEGI, P. TOTH, S. KEONUCHAN, T. NAGAI, K. KIKUCHI, N. MANABE, K.-P BRÜSSOW (2013): Saving genetic resources of native pigs in occidental and oriental countries - practical examples of the characterization and utilization of native pigs in Hungary and Laos. J. Reprod. Develop. 59, 437-441.

DOI: $10.1262 /$ jrd.2013-055

SABBIONI, A., V. BERETTI, V. PAINI, P. SUPERCHI (2011): Occurrence and inheritance of wattles and effects of genotype at wattle locus on Gompertz growth curve parameters in „Nero di Parma“ pigs. Livest. Sci. 137, 226-230.

DOI: $10.1016 /$ j.livsci.2010.11.009

SAS (2010): Statistical Analysis Systems User' Guide: Version 9.3. SAS Institute, Inc., Cary, North Carolina, USA

SASAKI, Y., Y. KOKETSU (2006): Variability and repeatability of gestation length across parity associated with reproductive performance in a cohort of gilts on commercial farms. J. Anim. Sci. 84 (Suppl. 1), 385.

SZULC, K., S. EWA, A. PANEK, D. KNECHT, A. JANKOWSKA, Z. SOBEK, D. STANISŁAWSKI (2011): Analysis of reproduction and litter performance of the Zlotnicka Spotted breed and its different crossbreeds. Ital. J. Anim. Sci. 10, 4.

DOI: $10.4081 /$ ijas.2011.e46

SZYNDLER-NĘDZA, M., P. LUCIŃSKI, Z. BAJDA (2010): Ochrona zasobów genetycznych świń ras rodzimych - stan hodowli i wyniki oceny. Instytut Zootechniki PIW z. 5, 3-24

ŠRAM, F. (1950): Domestic breeds of pigs in the Republic of Croatia. Newsletter of Breeding Association and Breeding Cooperative in Production, Zagreb, 7, 389-397 (in Croatian).

URANKAR, J., Š. MALOVRH, M. KOVAČ (2013): Dispersion parameters for litter size and teat number in Krškopolje pig. $8^{\text {th }}$ International Symposium on the Mediterranean Pig. Slovenia, Ljubljana, October $10^{\text {th }}$ to $12^{\text {th }}$. Acta Agr. Slov. 4, 57-60.

VENTANAS, S., J. VENTANAS, J. TOVAR, C. GARCÍA, M. ESTÉVEZ (2007): Extensive feeding versus oleic acid and tocopherol enriched mixed diets for the production of Iberian dry-cured hams: effect on chemical composition oxidative status and sensory traits. Meat Sci. 77, 246-256.

DOI: 10.1016/j.meatsci.2007.03.010

VUKINA, R. (1961): Pig breeding in practice. Znanje Publishing, Zagreb (in Croatian). 
S. Menčik et al.: Reproductive parameters in Banija Spotted pig breed

WHITTEMORE, C. T. (2006): Whittemore' s Science and Practice of Pig Production. Blackwell Publishing, Oxford, 3. pp. 103-106.

Received: 19 July 2018

Accepted: 17 January 2019

\section{MENČIK, S., V. KLIŠANIĆ, M. ŠPEHAR, Ž. MAHNET, D. ŠKORPUT, Z. LUKOVIĆ, D. KAROLYI, A. EKERT KABALIN, K. SALAJPAL: Reproduktivni pokazatelji banijske šare svinje tijekom revitalizacije pasmine. Vet. arhiv 89, 183- 199, 2019.}

\section{SAŽETAK}

Cilj ovoga istraživanja bio je procijeniti reproduktivne pokazatelje u populaciji banijske šare svinje. Istraživanjem je bilo obuhvaćeno 69 umatičenih krmača prema rednom broju prasenja (prvopraskinje, drugopraskinje, trećepraskinje, četvrtopraskinje i petopraskinje zajedno te skupna analiza svih prasenja). Deskriptivnom statističkom obradom analizirani su pokazatelji: dob jedinke kod pripusta i prasenja, starost nerasta kod pripusta, trajanje gravidnosti i međuprasidbeno razdoblje; pokazatelji veličine legla (VL): ukupan broj oprasenih (UO), živooprasenih (ŽO), mrtvooprasenih (MO) i odbijenih odojaka (OD). Prikupljeni podaci analizirani su linearnim modelom izračuna (GLM), dok je Pearsonov koeficijent korelacije (r) korišten za izračun povezanosti između pokazatelja veličine legla. Utvrđeno je prosječno 8,26 UO, 7,57 ŽO, 0,67 MO i 6,95 OD odojaka. Statistički znakovita razlika $(\mathrm{P}<0,05)$ utvrđena je između prvopraskinja i drugopraskinja te prvopraskinja i trećepraskinja s obzirom na UO i ŽO. Također je statistički znakovita razlika $(\mathrm{P}<0,05)$ utvrđena u broju OD odojaka između prvopraskinje i drugopraskinja te trećepraskinja odnosno četvrtopraskinja i petopraskinja zajedno. Trajanje gravidnosti i sezona prasenja znatno su utjecali na broj ŽO u drugopraskinja. Veličina stada, tj. grupe stada statistički znakovito je utjecala $(\mathrm{P}<0,05)$ na starost nerasta kod pripusta, odnosno broj živooprasenih u trećepraskinja. Analizom četvrtopraskinja i petopraskinja zajedno zabilježen je statistički znakovit utjecaj $(\mathrm{P}<0,05)$ starosti nerasta na broj UO, ŽO i OD odojaka, kao i trajanje gravidnosti na broj mrtvooprasenih. Vrlo visoka $(r=0,7-0,9)$ i statistički znakovita povezanost $(P<0,05)$ zabilježena je između UO i ŽO, UO i OD te ŽO i OD odojaka skupnom te pojedinačnom analizom prasenja, s najvišom vrijednošću korelacije $(r=0,94)$ između ŽO i OD odojaka analizom četvrtopraskinja i petopraskinja zajedno. U odnosu na druge lokalne pasmine, banijsku šaru svinju možemo smatrati pasminom umjerene plodnosti.

Ključne riječi: banijska šara svinja; krmače; veličina legla; revitalizacija

Vet. arhiv 89 (2), 183-199, 2019 
